\begin{tabular}{l} 
RCCS \\
\hline Annual Review
\end{tabular}

\section{RCCS Annual Review}

A selection from the Portuguese journal Revista Crítica de Ciências Sociais

$2 \mid 2010$

Issue no. 2

\title{
The Janus Model of Legal Regulation: Changes in the Political Status of Justice
}

\section{Jacques Commaille}

Translator. Sheena Caldwell

\section{OpenEdition}

\section{Journals}

Electronic version

URL: http://journals.openedition.org/rccsar/239

DOI: $10.4000 /$ rccsar.239

ISSN: 1647-3175

Publisher

Centro de Estudos Sociais da Universidade de Coimbra

\section{ELECTRONIC REFERENCE}

Jacques Commaille, « The Janus Model of Legal Regulation: Changes in the Political Status of Justice », RCCS Annual Review [Online], 2 | 2010, Online since 01 October 2010, connection on 19 April 2019. URL : http://journals.openedition.org/rccsar/239 ; DOI : $10.4000 /$ rccsar.239 


\section{Jacques Commaille}

Institut des Sciences Sociales du Politique, École Normale Supérieure de Cachan, France

\section{The Janus Model of Legal Regulation: Changes in the Political Status of Justice*}

Based on a social science perspective that gives priority to the political dimension of law and justice, this paper analyses three orientations of justice: as part of a rationalization process; as part of a democratization movement; and as part of a process of neoliberalization. From the analysis of these three types of legal regulation, two distinct forms of legal and judicial status may be identified in relation to the political: in the first, the legal-judicial is a central element in political regulation, while in the second it is instrumentalized by the political. The conclusion suggests that the existence of this Janus model of legal-judicial regulation points to a crisis in the political sphere.

Keywords: Democratization; neoliberalism; rationalization of justice; judicial regulation; legal regulation; political regulation.

Although there is a representation within the legal sphere concerning the possibility of selfdetermination in law (based on "Reason") and in justice (based on the notion of "fairness"), it is the responsibility of the social sciences to unveil what might be the social and political determinants of legal and judicial activity. This work of uncovering is all the more important as we live in a historical period in which actors in the legal and judicial spheres, like those operating in the political or state arena, cannot presume to impose a sole concept of law and justice.

This is why it is particularly pertinent to draw on political sociology to address this matter. In fact, we need to break with the illusion that the status of law and justice depend only upon a voluntaristic policy on the part of the actors involved. This illusion allows us to assume that, in this domain as in others, governmental stimulation, intervention from the state and public authorities (whether or not inspired by jurists and magistrates, in accordance with the principle of top-down regulation) is enough to bring about an adjustment to the established objectives. Far from depending solely on the political will of a central authority that could be instructed in the appropriate course of action on the matter, the question of law and justice entails political, institutional, social and cultural challenges that have to be taken into account before any prescriptions can be made.

For this reason, making use of a distinction that is common in the political sciences, I have replaced here the concept of "public policy" with that of "public action." This replacement

\footnotetext{
* Article published in RCCS 87 (December 2009).
} 
identifies an analytical approach that takes account of the actions not only of public institutions but also of the various public and private actors in civil society and the governmental sphere who act jointly in multiple interdependencies at national, local and ultimately supranational level to produce forms of regulation of collective activities in matters of law and justice. Public action is the result of multiple configurations of interdependent relationships and interconnected strategies of actors, public action networks and action systems, in accordance with a decision-making scheme that results from an accumulation of negotiated regulations and power relations, and that takes place along intersecting, horizontal and circular lines, rather than obeying a linear or hierarchical logic (Commaille, 2009). This sociology of public action is simultaneously a political sociology. Indeed, there is nothing more political than law and justice, and nothing involves challenges that are more properly political (Commaille \& Kaluszynski, 2007). More precisely, political sociology seeks to "analyse political processes in relation to society" because "a complete analysis of politics, from the point of view of action, cannot be limited to a consideration only of the political sphere in the strict sense, while neglecting the other spheres of social action." As Max Weber held, this involves studying "politics in its relations with the social orders and social forces" (Duran, 2010).

This contextualization of law and justice becomes all the more important as our societies are facing real political, economic, social and cultural changes. Thus, the status of law and justice should be related to what I shall call a "detraditionalization" movement, after Ulrich Beck (1992). In the so-called "advanced" societies, that status seems to arise from what we might call the crisis of conventionalism (Pharo, 1991), the advent of a "second modernity" (Beck, 1992), of an "advanced modernity" (Giddens, 1992) or of a "liquid society" (Baumann, 2000). It results from the extinction of a dominant, the decline of ideologies, the questioning of large institutions, and particularly the weakening of framing and social control institutions. In this context, it is significant that, in a country such as France, the state should have moved from a position of dominance to one in which it is a partner in public action that arises from the (sometimes conflictual) participation of multiple public and private actors (Duran, 2010; Commaille \& Jobert, 1998).

As was anticipated and analysed in a masterly fashion by Boaventura de Sousa Santos, precisely with regard to law and justice (Sousa Santos, 1988; 2004), nothing better illustrates these mutations than the phenomenon of deterritorialization to which justice is exposed, or 
in other words, the modification of its traditional territories of intervention (Commaille, 2000). Just as institutionalized territories appear to be less and less relevant given the nature of the problems that arise, showing a growing maladjustment of the political system to citizens' needs and expectations, justice does not escape the new forms of interpellation arising from society. Justice as an institution is forced to submit to contingencies and admit that it is the actors embedded in specific territories that determine how problems are defined and how public institutions are coordinated.

Justice was organized in accordance with the idea of "territories of public power," which is substantiated in France through the existence of "Palaces of Justice," together with other expressions of republican monumentality or transcendental power, like cathedrals. But these territories are now contested by "territories of management of social problems" (Duran, 2010), such as those constituted by urban spaces on the edge of large cities where problems of social segregation, ethnic repression and economic disadvantage are concentrated.

This pressure of the local upon justice is accompanied in the opposite direction by a growing pressure from the supranational, corresponding to a destabilization of the territories of the nation-state: "A dialectic of global and local has developed that tends to pass over intermediate levels, such as the nation" (Veltz, 1998: 332). As regards the fragmentation of sovereignty and the segmentation of power that characterise contemporary societies, it is now necessary to implement multinational control mechanisms, particularly with regard to justice, that are able to deal with the atomization of practices that go beyond national level, for example in matters of economic regulation (Arnaud, 2003). The economic domain is precisely a case in point, given that the globalization of financial flows and the constitution of a transnational economic space take the form of multilateral economic agreements, "reconfiguring productive apparatuses into a network," freeing "companies from the power relations previously negotiated at national level" and forcing "trade unions of both North and South to rethink their modes of acting". ${ }^{1}$

In this context of change, the fate of justice is inseparable from that of law, which is simultaneously its reference and its instrument of action (i.e. associated with alterations to the status of law itself). For example, French justice was inspired by a legal rationality related

\footnotetext{
${ }^{1}$ See the analyses presented in the website of the Social Responsibility and Sustainable Development Research Chair, University of Quebec, Montreal, http://www.crsdd.uqam.ca.
} 
to a kind of transcendental Reason. From this perspective, the advent of the Republic did no more than perpetuate a certain idea of law, now related to the state instead of religion (Legendre, 1974). This law, which contributed to a pyramidal representation of political regulation, could only lead to the idea of a "Jupiterian" model of justice: "A pyramid takes shape, an impressive monument that draws the gaze irresistibly upward towards that focal point from which all justice radiates" (Ost, 1992: 242). But this essentialist conception is increasingly giving way to a concept of legal reference that is more flexible, negotiated, relativistic and pragmatic, to the point of blurring the gap between Romano-Germanic law and common law, between law in books (which affirms a body of universal rules of justice based on a body of substantial law) and law in action (where the concern to find solutions appropriate for each case justifies the existence of a procedural justice whose emphasis is not so much on ends as on means and procedures to which actors resort to establish their objectives).

These changes in legal activity connected to the change in the status of law are clearly observable in processes of law production. The law is increasingly the result of interventions by multiple actors and spheres (Commaille, 1994). Its production and application involve a negotiated process that authorizes a structure made more of organizational rules than norms of content (Lascoumes, 1994), giving rise to a continuous process of successive appropriations (Hawkins et al., 1984) or promoting obligations and incitements to negotiate at local level (Gavini, 1998). The redefinition of the status of the state and the growing impossibility of political power to impose legislation in accordance with its own principles of action create conditions for social movements and relevant actors to influence legislative processes, including the initiative to put them into practice (Commaille, 2006). In this context, the law is also likely to operate as a resource to which political power can resort after all other forms of legal-political management have been exhausted (Galembert, 2007).

The present redefinitions of law and justice within the ambit of the social sciences illustrate these changes perfectly (Commaille, 2006). The certainties once held by the French sociology of law, largely a sociology of state law, have been shaken. Since we observe that "the state as the central element of regulation in modern societies is being challenged," the problem of the status of law is raised to the extent that it has become an expression of state regulation (Duran, 1993) - and, consequently, the general orientations of the French sociology of law are also called into question. It may be significant that the anthropology of 
law, in its classical posture, now appears better equipped to explain the current mutations. In truth, it has long conceived of societies where order derives from the society itself, thereby conceiving law as a function of the expectations, representations and practices of those that use it, as opposed to an approach to law and justice inspired by Western thinking, in which the structuring of the world is seen as an exclusive matter of those laws that are imposed from outside by a dominant omniscient authority.

In these new perspectives of analysis, it would seem that the fates of law and justice are inseparable. We find ourselves in a context in which the law of intangible reference has become a resource appropriated by social actors in accordance with their own aims. For example, the hierarchy of rules may be challenged in order to impose the value of a collective convention upon that of a law (Ledoux, 2006). Legal appeal may be used in accordance with certain strategies, and in the context of a given configuration of power relations. In this context, the institutionalized place of justice is likely to turn into an "arena" (in the sense used by political scientists) in which different appropriations of that legal reference confront each other, and where the aim is not so much to obtain a favourable verdict as to help promote a cause or impose an issue as a matter for public debate by projecting it into the public sphere. Thus, justice becomes even more a space where strategies are manifested and compared, including those of the magistrates who do not want to submit their action to a strict legal positivism or to make it the result of a causal association between the ethos of their professional body and a certain type of political behaviour. The law is in fact a parameter of action with which magistrates can also "play" (Osiel, 1995: 505, quoted by Israël, 2005). Thus, the concept of law that emerges is that of "a system of potentialities from which specific rule-mobilizing activities are played out" (Lascoumes, 1990: 50). In a context in which the idea of action is affirmed, in both political space and in the management of social and economic relations, as less an expression of a will than the result of multiple interrelations, of numerous exchanges between actors with diverging or contradictory interests, the law of reference becomes effectively a tool of action and eventually a means to which social actors or economic agents can resort.

To stress in this way the extent of the transformations affecting law and justice does not mean to implicitly impose the idea of a linear evolution that could justify a kind of pseudosociological prophetism. In this domain as in others, it is necessary to admit the existence of contradictory logics and, consequently, possible tensions between those logics, so that the 
change is less a controlled end of a tendency and more what results, in part involuntarily, from the confrontation between possible logics.

It is in this spirit that I focus upon the diverging orientations of justice, such as those that are manifested in the present, each one bringing a different fundamental conception of legal regulation as political regulation. Thus, I shall analyse in turn the forms taken by justice in (1) an economy of legal regulation as a process of rationalization, in (2) an economy of legal regulation as a process of democratization, and in (3) an economy of legal regulation as a process of neoliberalization. It remains to ask ourselves about the meaning that should be given to these different forms of legal regulation from the political point of view.

\section{Legal regulation as a process of rationalization}

Justice is increasingly compelled to align its modes of organization with those of "ordinary" administrations. One of the great specificities of justice was its extraordinary capacity to cultivate its exceptionalism, which was measured, for example, by its obstinacy in defending an a-economic, a-financial and a-organizational view of its functioning. This was reproduced in a representation of magistrates as fulfilling a mission of justice in an a-mercantile space outside ordinary interests (Commaille, 2000). The representation of justice as an institution was inspired by the extraordinary nature of the functions it fulfilled, which had an implicit reference to the idea of transcendence (see, for example, law court architecture, rituals, etc). Attempts at reform in France thus reveal an opposition, which we could almost classify as fundamentally cultural, between a ministry of finance concerned with the rational use of resources and a ministry of justice clinging to the idea of preserving its position outside the common world and bureaucracy (Commaille, 2000). But, for some years now, some countries, and especially France, have seen the tendency to align justice with other public institutions through the introduction of the "new public administration" (Schoenaers, 2003; Vigour, 2006). This concern seems to prevail over all others, particularly over the purposes of the mission of justice, to the point that political debates about justice are diluted in technical discussions about the organizational optimization of judicial practice (Vauchez \& Willemez, 2007).

Hence, justice can no longer escape the historical processes of rationalization of public structures and is increasingly exposed to a process of vulgarization of its function, as can be seen in the observation that "justice is a public service." A "reforming common sense" has 
thus been established (Vauchez \& Willemez, 2007) in which notions of costs, efficacy, quality of production (assessment of performance indicators) and assessment of action are paramount. This implies a "logic of results" and justifies the application of criteria of operational rationalization, cost reduction and "economies of scale" (as stipulated by the New Public Management) to "good work," defined increasingly in accordance with an exogenous model that is valid for all administrations and that has been imported into justice (Bezes, 2009). This is illustrated, for example, by the experiments at rewarding performance, with the introduction of awards for the French magistrates of the Court of Appeals and the Supreme Court of Judicature (Cour de Cassation) (Chellé, 2010).

It is certainly this new general spirit of justice that favours the local initiatives on the part of magistrates to introduce technological innovations, including videoconferencing. A recently published report on the introduction of new technologies into the functioning of justice emphasises the fact that the expansion of videoconferencing is inescapable, and that the policy of developing this technique in legal proceedings has been based on the business management model. The arguments used are primarily related to the question of economy of means, in the context of a policy of justice that is increasingly becoming similar to a managerial policy (Dumoulin \& Licoppe, 2009). This alignment of justice (till now so concerned with cultivating its exceptionalism) with the general tendency of all administrations to introduce this "new public management" into its organization and functioning contributes to a technicisation of justice and a correlative euphemisation of the political dimension.

This alignment is part of the context of the so-called advanced industrial societies. The question of state reorientations in order to reduce public spending constitutes an element of the context in which justice policies are inscribed. In keeping with the desire of supranational organizations such as the World Bank to preserve, restore and promote the rule of law, there is also a concern with making the justice systems of different countries fall into step with the rationalization process described by Max Weber (1921), a process corresponding to modern capitalism's need for a reliable legal and judicial system, both for the stability of its jurisprudence and for the transparency of its procedures.

It is significant that the justification of such a development can take the form of a doctrinal current applied to the legal and judicial sphere. This is manifested in the emphasis given to a concept of justice and law that we might call technocratic. For some authors, this 
is a question of renouncing fixed, pre-established rules. In this perspective, law cannot continue to be considered an immutable reference, but rather an instrument of public policy, with rules inscribed in public action, that is, in the framework of a managerial model of government. In this regard, it is important to recognise the pertinence of the new legal doctrines and to break with a concept that implies loyalty to all pre-existing legal principles, in the name of a new vision of the state that demands a more active approach to law, an approach that can contribute to active policy making. In keeping with this doctrine, the growth of a bureaucratic state requires a mode of regulation that is no longer based on a mechanism that establishes a balance between opposing forces, but rather on the coordinated efforts of a central authority that combines the production of rules, the activity of judging and the monitoring of policy application. Consequently, Montesquieu's threepower structure is considered obsolete and replaced by the concept of an "efficient and coherent" exercise of power, according to which courts should break with the tradition that insists that they cling to a concentration on judging. In this context, Judicial Policy Making should be part of the modern concept of the state. Judges should become policy makers because policy making has become the main way of describing governmental action (Feeley \& Rubin, 1998).

Thus, it is possible to claim that the managerialization of justice is part of a managerial concept of government, and that this presupposes a managerialization of law, which specialists in public law speak about in their reflections on governance and law. A study of the reform of the judicial map in France in 2008 confirms this correspondence (Commaille, 2009). This process was marked primarily by an attempt to get around parliament. In choosing to launch the reform through decrees, rather than through an Act, the promoters of the reform were visibly trying to avoid a debate with parliament, since the history of the judicial map teaches us that it often constitutes an obstacle to all alterations in this matter. As happened with the reform that took place in France in 1958 (Commaille, 2007), there was here a desire on the part of the executive to reappropriate control over a reform process that was running the risk of being contested or even annulled by the legislative branch. However, in avoiding parliament, there was a transfer of the debate and of the expression of power relations from this space to the council of state. The breadth of the resources deployed was then in accordance with the mobilizations that the reform provoked. Paradoxically, in the light of what we might generally consider to be an impoverishment of 
the legal field in this process, these mobilizations entered the terrain of political struggle by resorting to the legal field, represented by the recourse against the founding decrees of the reform. The real threat that such a strategy might pose cannot be better illustrated than in the "renunciation" of the initial decrees that constituted the legal grounds of the reform and the recourse to the "simple" decree, which enabled a power confrontation of uncertain outcome to be avoided within the "law factory" of the council of state. The choice of this strategy of "simple" decree at the (provisional?) end of a reform process is clearly an extreme example of the instrumentalization of the legal field, which is put at the service of a managerial model of government. In short, the main aspects of this reform were as follows: the extreme fragility of its legal grounds, suppression measures that strictly obeyed an "accounting model," and disqualification of the conciliation device, since the Advisory Committee of the judicial map, created at the beginning of the process but which never met, was in practice replaced by the hasty work of a small group of actors related to the Ministry of Justice. All these aspects constitute an unequivocal example of the shift from a "juridical state" to a "managerial state" (Caillosse, 2009), in this case involving an increasingly evident kind of "political marketing." Priority is given to efficiency and performance rather than to the regularity and legitimacy of state interventions. We are pushing back "the legal culture of regularity in favour of a result-based managerial culture" (Caillosse, 2009; 2008), and all this, finally, in the name of a "lawless governance," in the words of one author (Mockle, 2007).

\section{Legal regulation as democratization process}

The term "judicialization" (as in "the judicialization of society" and "judicialization of politics") is now increasingly used to describe the way in which the role of justice has supposedly been extended to the management of social relations, the "problems of society," transgressions (from common delinquency to political delinquency, corruption and "crimes against humanity"), and the regulation of economic exchanges (Commaille \& Dumoulin, 2009). This "judicialization" does not only manifest itself in an increase in litigation brought before institutionalized and professionalized justice, but it may coexist with a decrease in litigation (we should note the case of civil justice in Quebec), as new forms of justice emerge. I will not go into what, in this observation of "judicialization," derives from actual fact, from a growing demand and expectation in relation to justice, and what derives from the social 
representations of legal professionals seeking to substantiate this supposed reality. The fact that "judicialization" has been heavily debated and written about at international level (Commaille \& Dumoulin, 2009) offers a strong indication that the matter of justice lies at the heart of the questions raised by contemporary societies concerning its functioning and its future, which are far beyond opinions about justice or the effective recourse to justice. Nothing demonstrates this better than analyses about the "judicialization of politics." This involves a global expansion of judicial power (Tate \& Vallinder, 1995), meaning that "decision-making power is transferred to the courts" (Fournier \& Woerlhing, 2000). "Judicialization" is then defined as an increase in the power of courts in relation to the legislative and executive powers.

How is this phenomenon of "judicialization" manifested in analyses? It is frequently associated with what would be a process of democratization. Martin Shapiro considers that the legitimacy of the political regime may be accompanied by the intervention of justice in the allocation of economic resources or in the establishment of real social policies (Shapiro, 1994). Thus, we see that, on the international level, the courts are, not infrequently, agents of public policy, and aspire to be so, even though many analyses emphasise their incapacity for this role (Horowitz, 1977). That is the case in the United States, where the courts intervene in matters of integration, police control, environmental protection, improvement of living conditions for the poorer members of society, and protection of civil rights, minority rights, women's rights, etc. (Horowitz, 1977). But similar developments have occurred in other countries, such as those of Latin America. In Colombia, the protection of social rights is guaranteed by the judiciary, and the courts and Constitutional Court intervene on matters of economic policy, especially by annulling laws to raise VAT on essential products, ordering the partial indexation of employees' salaries, extending retirement pensions to certain groups of the population that had been excluded, prohibiting the elimination of benefits for pensioners, etc. (Uprimny Yepes, 2007).

However, "judicialization" is manifested even more in areas that concern the general principles of democracy, thereby justifying its association with the idea of democratization. Thus, there has been an increase in the importance of the role of the Supreme Courts with regard to social progress, the defence of human rights and those of the weakest or more disadvantaged members of society, equal opportunities, etc. Some authors speak of a "Rights Revolution" (Epp, 1998), which gives common citizens access to the benefits of 
justice, as this is grounded in the defence, acquisition and reinforcement of new rights. These judicial policies are believed to be more effective if they are based upon a dynamic civil society and provision of public funds, that is, a "support structure for legal mobilization" (Epp, 1998). In India, the role of the Supreme Court is growing with regard to the promotion of democratic principles, a more substantial concept of equality, supervision of electoral processes, etc. (Mehta, 2007). This may be illustrated by Public Interest Litigation, which permits all citizens to appeal if they have been victims of an injustice (an "alleged evil") (Mehta, 2007).

This intrusion of justice into the political sphere may be supported by forms of justice that are quite different from the institutionalized form represented by the Supreme Court. Thus, "Truth and Reconciliation" committees are in fact forms of justice that merely make use of legal rules, thus breaking the law professionals' monopoly on justice, drawing inspiration from the idea of restorative justice, to function as "structures of democratization and social pacification" (Lefranc, 2007). Finally, in this process of "judicialization" of politics, it is useful to assess the influence of the justice professionals themselves, as is suggested by the example of the process of establishing the notion of universal jurisdiction (even if politics and nation states are maintained as important agents in the process) (Seroussi, 2009).

This analysis of the new role played by justice in the social and political regulation of contemporary societies should also take account of the new relations between the citizens themselves and justice, and the new relations of organized forms of mobilization within civil society, i.e. social movements. No one analyses this aspect better than the American author Michael McCann, particularly in his book Rights at Work (1994). In this perspective, the mobilisation of law, especially to reinforce the power of marginalized citizens or even the power of ordinary citizens, is part of a political process. According to Michael McCann, law simultaneously provides normative principles and strategic resources for the materialization of social struggles. Empirical support for his analysis was principally provided by the collective actions brought by trade union jurists with respect to pay equity in the United States, particularly with regard to women, but also involving individuals that are poorly paid or undervalued due to their sexual orientation or ethnicity.

Thus, for Michael McCann, using law and justice as a resource, transforming them into favoured instruments in the repertoire of collective action of social movements, leads to the establishment of a true bottom-up jurisprudence. Moreover, the effects of these strategies in 
relation to law and justice are not only real and concrete but also symbolic, as they act upon citizens' representations of that to which they are subjected and of the possible role of law and justice, until they acquire a rights consciousness, an awareness of rights in general or of their rights in particular. Canadian studies offer other examples of these mobilizations of justice by civil society, of this shift of political space toward legal-judicial space, in order to deal with problems which, in principle, fall into the political sphere. Such mobilizations are also encouraged by the Canadian Charter of Rights and Freedoms of 1982 - for example, recourse to courts as a political strategy considering that the reference to fundamental rights may be a privileged means for establishing the ideology of "gay liberation" (Smith, 2005; Morton \& Allen, 2001).

These new investments in justice are likely to favour the emergence of new forms of justice, such as "Houses of Justice and Law," "Centres for Proximity Justice," or even mediation, conciliation, arbitration and alternative forms of conflict resolution. Lay actors (new professionals in the social field, movement activists, and even people in elected positions at local level) aim to take their place in these structures in order to be involved in the exercise of justice anchored in the new territories of social problems (Lejeune, 2007).

These new demands by civil society for a new bottom-up form of justice acquire even more importance as they are part of a trend towards transnationalization. In this context, social movements are increasingly involved in a worldwide civil society that leads them to rethink their strategies and renew their repertoire of collective action, particularly as regards possible uses of the judicial arena. This is particularly evident in the domains of ecology, urbanism, minority rights, women's rights, and obviously the economy (see the above reference to the analyses made by the Social Responsibility and Sustainable Development Research Chair, University of Quebec, Montreal).

These trends towards the reappropriation of justice by citizens and the movements representing them are accompanied and supported by justice professionals, within the framework of cause lawyering, that is, the work of lawyers who, according to Austin Sarat and Stuart Scheingold, rather than fulfilling their traditional function of representing their clients' interests, use their talents and any resources at their disposal to achieve political and social goals and promote their cause (Sarat \& Scheingold, 2006). The specific influence of the legal professionals is also manifested in the context of a movement that has been called political lawyering, in which lawyers contribute to the advancement of political liberalism, 
that is, the transformation of law and the state and the defence of individuals' fundamental rights and freedoms (Halliday et al., 2007). ${ }^{2}$

\section{Legal regulation as a process of neoliberalization}

We are in a context in which, typically, the return of economic liberalism is translated by a double movement of state decline in the economic and social domains. This movement accompanies the restoration of values of individual freedom, initiative and responsibility demanded by those that defend the primacy of the market. The classical counterpart to this is the return to state control in the penal domain, which attests to an international tendency towards "over-penalization" (Salas, 2005), illustrated by increased repression of minors to the detriment of prevention, or by what one author calls "penalization of the social" (Marry, 2003). The recurring reference to the rule of law simultaneously manifests a desire for greater market autonomy and a restoration of the penal. In this context, in which increased importance is given to the economic paradigm (Hall, 1993) and the market referential (Jobert, 1994), the weakening of the political dimension and the redefinition of the status of the state, concomitant with a growth in individual rights and a loss of faith in the social state, contribute to give the judge, in addition to a restored repressive function, a growing role as regulator in the management of social relations and economic exchanges and in the functioning of a policy that is endogenously constructed in the framework of social interactions, specifically in the judicial space.

However, the judge's new role does not simply result from these developments; they are also promoted by the judges themselves. For example, Ran Hirschl (2004), observing a strong international tendency towards a "juristocracy," examines how the interplay between economic elites and judicial elites contribute to this. According to this author, the actions of the judicial elite, particularly those operating in the Supreme Courts, tend to be inspired in individualistic liberal values (including on matters of customs) and opposed to the principles underlying the welfare state, which justified the existence of redistributive justice (manifested in the importance given to trade unions and social rights such as minimum salary, housing, social protection, etc). Thus, the triumph of the "juristocracy" is associated with the decline of an egalitarian vision in socioeconomic matters and adherence to the

\footnotetext{
${ }^{2}$ It should be noted, however, that this thesis has been hotly debated (Commaille, 2009).
} 
values of economic liberalism. In addition to the practices of the judges of the Supreme Courts, this new justice system is adapted to the new transnational boundaries of the market. Thus, we have seen the emergence of a transnational power exercised by agents invested with the functions of "justice," such as the experts of the International Monetary Fund (IMF), the World Bank and the World Trade Organization (WTO), or the judges operating in the various European tribunals or international criminal courts. New scales of judicial action are demanded to respond to the desire to ensure legal safety for economic agents from "peripheral countries" or from European countries previously belonging to the Soviet bloc. Supranational institutions like the World Bank, the European Commission and US Aid thus aim to promote the application of justice systems that can guarantee the credibility, stability and security necessary for trade by modernizing and rationalizing the judicial system, ensuring its autonomy in relation to politics and providing training for magistrates. For these supranational institutions, it is important to reduce the unpredictability of a judicial system that might constitute an obstacle to the development and growth of the market. For some, this attention given to justice aims less at instituting the rule of law than a state-endorsed "rule of business" (Sen, 2000).

In Japan, justice reform clearly points to an increasingly close connection between economic liberalism and justice, with the active participation of legal professionals. The pressure exerted by Japanese employers seems to have been decisive for justice reform "in the context of a market economy that values individual initiative" and in the name of a system that guarantees "total deregulation of the economy in order to maintain competitiveness in a globalized competitive world" (Takamura, 2007). This is what is effectively being undertaken by a liberal government with a view to increasing the number of judicial professions, setting up new Law Schools, fostering "the privatization of justice through companies and associations," which are encouraged to become agencies of conflict resolution within the framework of the basic laws about alternative forms of conflict resolution, in keeping with the general aim of promoting the adaptation of Japanese society to globalization (Takamura, 2007).

Following these general principles inspired in economic liberalism, a dual policy of access to law and justice is explicitly endorsed, according to the principle of market segmentation of law and justice. This dualism implies that the privileged classes and economic agents have access to an institutionalized and professionalized justice, while disadvantaged groups have 
access to a "lay" form of justice exerted by persons of uncertain competence. The problem becomes even more pertinent because, in the sphere of justice, a differentiation might arise between a sector dedicated to the management of interpersonal relations (such as the Portuguese justices of the peace) and a sector that responds to the needs of economic and administrative activities of organizations (Bastard \& Guibentif, 2007).

This neoliberal configuration is part of a process of "deformalization" of law and justice, in keeping with a context of "contractualization" that "may be nourished by anti-state positions, which aim more or less at the model of the 'minimal' state and an activation of civil society conceived as an atomized society connected by free voluntary exchanges" (Munck, 1995: 95).

In the sphere of a form of justice connected to neoliberalization, the phenomenon of judicialization acquires another hue. Judicial power is here clearly perceived as an active part of the neoliberalization process, as it finds in it the means to increase its power to the point of becoming an obstacle to democratization. Nothing illustrates better the intensity of this belief and its justification than the title of an article about the multiplication of constitutional courts during the 1990s in regions belonging to Russia: "Less Democracy, More Courts" (Trochev, 2004). We might also mention the controversies raised by the Canadian Charter of Rights and Freedoms of 1982, and the comments of one author for whom both the left and the right focused on the negative side of the growth of judicial power. The left lamented the fact that involvement in law presented a risk of depoliticization for social movements, while for the right, the Charter, in reinforcing the power of law and justice, made it possible for their professionals to enter the terrain of politics and policy production, thereby exceeding what ought to be their legal functions (Smith, 2005).

For Ran Hirschl, there is in fact a strategic interplay between the political, economic and judicial elites to favour the judicialization movement. In his book Towards Juristocracy, Hirschl (2004) returns to the frequently mentioned observation that, throughout the world, at both national and supranational level, there has been an unprecedented transfer of power from representative institutions to judiciaries. Based on a comparative analysis involving four countries (Canada, New Zealand, Israel, South Africa), Hirschl argues that the expansion of the power of justice via constitutionalization bears witness to a desire to preserve hegemonic interests. It is part of a context of social, political and economic struggles that shape the political system, and therefore cannot be understood in isolation 
from them. Thus the displacement of policy-making authority from majoritarian decisionmaking arenas to judicial arenas should be attributed to the political and economic elites, who consider that their interests are thus better served. ${ }^{3}$ For Hirschl, those "who are eager to pay the price of judicial empowerment must assume that their position (absolute or relative) would be improved under a juristocracy" (Hirschl, 2004: 11). This strategy is particularly developed by three key groups: political elites who feel threatened by new social groups and seek to preserve their interests and hegemony by bypassing democratic procedures, while professing support for democracy; economic elites, who perceive the constitutionalization of rights, particularly as regards property, mobility and employment, as a way of influencing government action and promoting a free market and an agenda favourable to their interests; and judicial elites and national high courts, which seek to strengthen their political influence and international reputation. In short, according to Hirschl, these are the strategic legal innovators (i.e. the political elites in association with the economic and judicial elites who have interests in common) which "determine the timing, extent, and nature of constitutional reforms" (Hirschl, 2004: 12).

For Hirschl, Israel offers an excellent example of the increase in power of the Supreme Court. Martin Edelman (1994) had already called attention to the increase in appeals to this jurisdiction. He calculated that the number of cases increased by $632 \%$ between 1956 and 1987 , while in the same period the population grew by $230 \%$; in 1987 , the court received 1466 petitions, seven times more than thirty years before. Moreover, this author observed that the Israeli Supreme Court had allowed itself more and more freedom in its interpretation of the country's basic laws (although there is no written constitution), largely invoking the rule of law and principles of natural law. For Edelman, the Israeli political system has thus changed, since the Supreme Court has now become an important political actor, having played only a secondary role during the early years of Israel's existence. In fact, it seems to have moved from a role similar to that played by the House of Lords in the British

\footnotetext{
${ }^{3}$ The issue of judicialization thus reignites the traditional debate about which elites gain the most from recourse to justice, undermining the idea that justice can contribute to social change. See the famous analysis by Marc Galanter (1974) and the critical assessment of it by Kritzer \& Silbey (2003); see also an analysis of a federal jurisdiction that concludes that jurisdictions may be more receptive than other political arenas to claims from disadvantaged groups, though they are also used by powerful social groups to reinforce their politically acquired gains (Olson, 1990).
} 
system to one that is more comparable with that of the United States Supreme Court (Edelman, 1994).

Hirschl, in accordance with his critical stance regarding judicialization, puts forward a three-point explanation to analyse the increase in Israeli judicial power: the hegemony of the elites is threatened by peripheral groups and their political orientation; judicial power benefits from a strong reputation for uprightness and impartiality; and jurisdictions have a tendency to decide in accordance with dominant ideological and cultural ideas (Hirschl, 2004). This issue had been discussed in an article in which Hirschl (2001) emphasises that the constitutionalization of rights in Israel is the product of a strategic alliance between the dominant elites, their political representatives and legal professionals. He shows particularly that the Israeli Supreme Court shares the values of an urban elite belonging to the Ashkenazi bourgeoisie, and that this proximity is even greater, for the latter actually control appointments. The judicial power has even more chances of exerting its influence when there is a widespread belief in its impartiality. However, Hirschl observes that the representatives of peripheral minorities are increasingly opposing judicial empowerment. Occupying an increasingly important space, they are seeking to impose a return to majoritarian policy-making arenas.

Summing up these observations in Towards Juristocracy, Hirschl stresses that, in the four countries studied, the growth of the judiciary is based on a strict conception of rights, based on Lockean individualism and on a dyadic and antistatist view of constitutional rights. This is, therefore, a way of protecting the private (human and economic) sphere from the pressures of the "collective" (often defined as the state and its forms of regulation). According to Hirschl, the high courts of the four countries view the state as a threat to human freedom and equality. For him, the legal discourse on rights is impregnated with all the fundamentals of social and economic neoliberalism, such as individualism, deregulation, the commodification of public services and reduction of public spending, inspired by antistatism, social atomism and the strict protection of the private sphere. In this spirit, what is endorsed is a procedural justice, less state intervention in the private sphere, and a general attitude of hostility toward claims for substantive equality, state regulation and workers' rights (Hirschl, 2004: 14; 147-8). Hirschl thus emphasises the existence of a global trend towards economic and social neoliberalism, visible in the four countries studied, with a weakening of the "Keynesian welfare state in favor of more market-oriented, 'small state' 
economic policies" (Hirschl, 2004: 155). Obviously, for this author, these developments do not reinforce distributive justice or improve the situation of disadvantaged groups.

In his conclusion, Hirschl suggests that the empowerment of the judiciary is likely to become more accentuated with the creation of supranational jurisdictions (he gives the European Court of Justice as an example) or even relatively autonomous agencies, such as the national central banks and the European Central Bank, or even transnational trade treaties. All this illustrates a trend towards the establishment of quasi-judicial procedures in different sectors, and the transfer of "policy-making prerogatives from majoritarian decisionmaking arenas to relatively insulated domestic and transnational policy-making bodies" (Hirschl, 2004: 216).

\section{Conclusion}

After analysing these three types of legal regulation of the economy, it is possible to extract two opposing forms of legal and judicial status in relation to the political. In the first, the legal-judicial dimension is a central element in political regulation, which can be illustrated by the three-part governance model defined by Alec Stone Sweet. For this author, the judicialization of dispute resolution is the process by means of which a TDR (triadic dispute resolution) mechanism arises, stabilises and develops authority over the normative structure responsible for managing exchange in a particular community (Shapiro \& Stone Sweet, 2002; Stone Sweet, 1999). For Alec Stone Sweet, this triad constitutes an essential mechanism of political change. In fact, the movement from dyad to triad corresponds to the advent of a particular form of governance that has to do with regulating behaviours and maintaining social cohesion in a context of change. The introduction of a new scale, manifested through the phenomenon of judicialization, "progressively shapes the strategic behavior of political actors engaged in interactions with one another" (Stone Sweet, 1999: 71) and leads, finally, to the gradual but inevitable redefinition of the nature of governance itself (Stone Sweet, 1999: 86).

The second form of legal-judicial status by reference to the political is marked by instrumentalization: either due to a prevailing concern for rationalization which leads law and justice to suffer a loss of meaning in favour of a managerial model that governs their application; or because law is placed at the service of a political marketing corresponding to 
a distorted conception of the political; or still when law and justice become instruments at the service of social agents and economic operators.

If we admit the existence of these two forms, it is possible to speak of a Janus model of legal regulation. But, as we have seen, this model is constructed in relation to the political, and this says more about the status of the political than about legal-judicial status. Legal regulation is systemically interconnected with political regulation. From this point of view, the Janus model of legal regulation immediately reveals a crisis in the political, specifically in the political model of representative democracy.

In the first form of legal-judicial status in relation to the political, the increasing supremacy of the legal-judicial means a weakening of the political. Thus, there is a kind of overinvestment in justice by default of the political, as the latter is unable to represent and impose a metareason.

Citizens [...] have turned towards Justice, resorting to it to compensate for the "democratic deficit" of political decision-making, which has become subordinated to management, and to provide society with a symbolic reference that present representation offers increasingly less. (Ringelheim, 1997)

Justice is the receptacle for a civilizational unease that exceeds it and questions the actors that constitute a society. The crisis in justice expresses the fear of insecurity produced by the mutation in a model of society [...] Behind the failure of justice, it is democracy that is being sought, and it is politics as an institution in a common world that is at stake. (Cartuyvels \& Marry, 1997)

We can thus interpret the observation of Louise Arbour, United Nations High Commissioner for Human Rights, as the expression of the need to impose upon the political a higher rationality which, from now on, only justice can offer: "Justice has reasons which political reason does not know" (Le Monde, 8th February 2007). We can include in the same line of reasoning a doctrinal current within the judicial sphere which, basing itself on the idea of the necessary rehabilitation of a "third power" embodied by the judge in the context of questioning the "Jacobin Republic" and "republican legicentrism" (Gauchet, 1995, Rosanvallon, 2002), professes a new role for the judge as arbitrator between civil society and the state (Salas, 1998) or institutes it as the "guardian" of democratic promises (Garapon, 1996). In this perspective, it is up to law and justice to confer a reason, being invested or overinvested as political reason by default of the political. 
In the second form of legal-judicial status in relation to the political, the instrumentalization of the legal and judicial is no more than an expression of another form of weakening of the political, of a political unable to define itself in accordance with its purposes or subordinated to economic logic, that is, the logic of means rather than ends.

It remains for us to explore the meaning of these expressions that sprout from the legaljudicial system and that contribute to the same phenomenon of decline of the political. Be it as it may, at this moment it seems that drawing on political sociology to analyse law and justice, as defined at the beginning and as I have tried to explain in this article, introduces a much broader question than the one that concerns the prospects for the development of the political - the emergence of new regimes of political regulation. Finally, the question that remains concerns the reorientations necessary for these political regulation systems to ensure the effective realisation of the democratic project, seeking to know how law and justice may ultimately contribute to the restoration of the political.

Translated by Sheena Caldwell

Revised by Teresa Tavares

\section{References}

Arnaud, Andre-Jean (2003), Critique de la raison juridique. 2. Gouvernants sans frontières. Entre mondialisation et post-mondialisation, Coll. Droit et Société. Paris: LGDJ.

Bastard, Bet; Guibentif, Pierre (2007), "Présentation. Justice de proximité: la bonne distance, enjeu de politique judiciaire," Droit et Société, 66.

Bauman, Zygmunt (2000), Liquid Modernity. Cambridge: Polity Press.

Beck, Ulrich (1992), Risk Society: Towards a New Modernity. London: Sage.

Bezes, Philippe (2009), Réinventer l'Etat. Les réformes de l'administration française (1962-2008). Paris: PUF.

Caillosse, Jacques (2009), "Quel droit la gouvernance publique fabrique-t-elle?" Droit et Société, 71, 461-470.

Caillosse, Jacques (2008), La constitution imaginaire de l'administration. Paris: PUF.

Cartuyvels, Yves; Marry, Philippe (1997), “Crise de la justice et au-delà?” L'affaire Dutroux. La Belgique malade de son système. Brussels: Editions Complexe, 97-127.

Chellé, E. (2010), "Une politique de récompense dans la haute-magistrature. Le cas de la prime de rendement," Droit et Société, forthcoming.

Commaille, Jacques (1994), L'esprit sociologique des lois. Essai de sociologie politique du droit, Coll. Droit, Ethique et Société. Paris: PUF. 
Commaille, Jacques (2000), Territoires de justice. Une sociologie politique de la carte judiciaire. Paris: PUF.

Commaille, Jacques (2006), "Nouvelle économie de la légalité, nouvelles formes de justice, nouveau régime de connaissance. L'anthropologie du droit avait-elle raison?" in C. Eberhard \& G. Vernicos (eds.), La quête anthropologique du droit. Paris: Karthala, 351-368.

Commaille, Jacques (2009), "Sociologie de l'action publique," Dictionnaire des politiques publiques. Paris: Presses de Sciences Po, new edition.

Commaille, Jacques, Review of Fighting for Political Freedom. Comparative Studies of the Legal Complex and Political Liberalism (2007), by T.C. Halliday, L. Karpik \& M.M. Feeley (eds.), L'Année Sociologique, 2 (59), 449-456.

Commaille, Jacques; Jobert, Bruno (eds.) (1998), Les métamorphoses de la régulation politique. Coll. Droit et Société, série Politique. Paris: LGDJ.

Commaille, Jacques et Kaluszynski, Martine (eds.) (2007), La fonction politique de la justice. Paris: la Découverte.

Commaille, Jacques; Dumoulin, Laurence (2009), "Heurs et malheurs de la légalité dans les sociétés contemporaines. Une sociologie politique de la 'judiciarisation'," L'Année Sociologique, 59(1), 63-107.

Dumoulin, Laurence; Licoppe, Christian (2009), "Justice et visioconférence: les audiences à distance. Genèse et institutionnalisation d'une innovation," Rapport pour le GIP Mission Recherche Droit et Justice. Paris.

Duran, Patrice (1993), "Piloter I'action publique, avec ou sans le droit?" Politiques et Management Public, 11(4), 1-45.

Duran, Patrice (2010), "Action publique, pouvoir politique et sciences sociales. Post-face," Penser I'action publique. Paris: LGDJ-Lextenso éditions, new edition.

Edelman, Martin (1994), "The Judicialization of Politics in Israel," International Political Science Review, 15 (2), 177-186.

Epp, Charles R. (1998), The Rights Revolution. Lawyers, Activists, and Supreme Courts in Comparative Perspective. Chicago, London: The University of Chicago Press.

Feeley, Malcolm M.; Rubin, Edward L. (1998), Judicial Policy Making and the Modern State. How the Courts Reformed America's Prisons. Cambridge, New York: Cambridge University Press.

Fournier, Bernard; Woehrling, José (2000), "Présentation du numéro Judiciarisation et pouvoir politique," Politique et Sociétés, 19(2-3), 3-7.

Galanter, Marc (1974), “Why the 'Haves' Come out Ahead: Speculations on the Limits of Legal Change," Law and Society Review, 9, 95-160.

Galembert, Claire de (2007), "La fabrique du droit entre le juge administratif et le législateur. La carrière juridique du foulard islamique (1989-2004)," in J. Commaille \& M. Kaluszynski (eds.), La fonction politique de la justice. Paris: La Découverte, 95-118.

Garapon, Antoine (1996), Le gardien des promesses. Justice et démocratie. Paris: Ed. Odile Jacob.

Gauchet, Marcel (1995), La révolution des pouvoirs. La souveraineté, le peuple et la représentation. Paris: Gallimard. 
Gavini, Christine (1998), Emploi et régulation. Les nouvelles pratiques de l'entreprise. Paris: CNRS Editions.

Giddens, Anthony (1992), The Transformation of Intimacy: Sexuality, Love, and Eroticism in Modern Societies. Stanford: Stanford University Press.

Hall, Peter A. (1993), "Policy Paradigms, Social Learning and the State," Comparative Politics, 25(3), 275-292.

Halliday, Terence C. et al. (2007), Fighting for Political Freedom. Comparative Studies of the Legal Complex and Political Liberalism. Oxford, Portland: Hart Publishing.

Hawkins, Keith et al. (1984), Environment and Enforcement Regulation and the Social Definition of Pollution. Oxford: Oxford University Press.

Hirschl, Ran (2001), "The Political Origins of Judicial Empowerment through Constitutionalization. Lessons from Israel's Constitutional Revolution," Comparative Politics, 33(3), 315-335.

Hirschl, Ran (2004), Towards Juristocracy. The Origins and Consequences of the New Constitutionalism. Cambridge, Mass.: Harvard University Press.

Horowitz, Donald L. (1977), The Courts and Social Policy. Washington: The Brookings Institution.

Israël, Liora (2005), Robes noires, années sombres. Avocats et magistrats en résistance pendant la Seconde Guerre mondiale. Paris: Fayard.

Jobert, Bruno (1994) (ed.), Le tournant néo-libéral en Europe, Coll. "Logiques Politiques". Paris: L'Harmattan.

Kritzer, Herbert M.; Silbey, Susan (eds.) (2003), In Litigation. Do the 'Haves' Still Come Out Ahead? Stanford: Stanford University Press.

Lascoumes, Pierre (1990), "Normes juridiques et mise en œuvre des politiques publiques," L'Année Sociologique, 40, 43-71.

Lascoumes, Pierre (1994), L'éco-pouvoir. Environnements et politiques. Paris: La Découverte.

Ledoux, Clémence (2006), "La construction politique du métier d'assistante maternelle," Master's thesis, IEP Paris.

Lefranc, Sandrine (2007), "La justice dans l'après-violence politique," in J. Commaille \& M. Kaluszynski (eds.), La fonction politique de la justice. Paris: La Découverte, 273-291.

Legendre, Pierre (1974), L'amour du censeur. Essai sur l'ordre dogmatique. Paris: Le Seuil.

Lejeune, Aude (2007), "Justice institutionnelle ou justice démocratique. Clercs ou profanes. La Maison de justice et du droit comme révélateur des tensions entre des modèles de justice," Droit et Société, 66.

McCann, Michael W. (1994), Rights at Work: Pay Equity Reform and the Politics of Legal Mobilization. Chicago: University of Chicago Press.

Marry, Philippe (2003), Insécurité et pénalisation du social. Bruxelles: Labor.

Mehta, Pratap B. (2007), "The Rise of Judicial Sovereignty," Journal of Democracy, 18(2), April, 70-83.

Mockle D. (2007), La gouvernance, le droit et l'Etat. La question du droit dans la gouvernance publique. Brussels: Bruylant.

Morton, Frederick L.; Allen, Avril (2001), "Feminists and the Courts: Measuring Success in Interest Group Litigation in Canada," Canadian Journal of Political Science, XXXIV(1), 55-84. 
Munck, Jean de (1995), "Le pluralisme des modèles de justice," in Antoine Garapon \& Denis Salas (eds.), La justice des mineurs. Evolution d'un modèle. Brussels, Paris: Bruylant, LGDJ, 95.

Olson, Susan M. (1990), "Interest Group Litigation in Federal District Court: Beyond the Political Disadvantage Theory," Journal of Politics, 52(3), 854-882.

Osiel, Mark (1995), "Dialogue with Dictators: Judicial Resistance in Argentina and Brazil," Law and Social Inquiry, 20(2), 481-550.

Ost, François (1992), "Jupiter, Hercule, Hermès: trois modèles de juge," in P. Bouretz (ed.), La force du droit. Panorama des débats contemporains. Paris: Esprit, 241-272.

Pharo, Patrick (1991), Politique et savoir-vivre: enquête sur les fondements du lien civil. Paris: L'Harmattan.

Ringelheim, Foulek (1997), "Feux sur la justice," L'affaire Dutroux. La Belgique malade de son système. Brussels: Editions Complexe.

Rosanvallon, Pierre (2002), Le peuple introuvable. Histoire de la représentation politique en France, Coll. Folio Histoire. Paris: Gallimard

Salas, Denis (1998), Le tiers pouvoir. Vers une autre justice. Paris: Hachette Littératures.

Salas, Denis (2005), La volonté de punir. Essai sur le populisme pénal. Paris: Hachette Littératures.

Sarat, Austin; Scheingold, Stuart A. (2006), Cause Lawyers and Social Movements. Stanford: Stanford University Press.

Schoenaers, Frédéric (2003), "Disponibilité des ressources et innovations managériales. Quelles mutations pour les juridictions du travail belges et francaises face aux évolutions de leurs environnements," Doctoral dissertation, IEP Paris, University of Liège.

Sen, Amartya (2000), Un nouveau modèle économique. Développement, justice, liberté. Paris: Odile Jacob.

Seroussi, Julien (2009), "Les acteurs nationaux du droit pénal international: le cas Pinochet," l'Année Sociologique, 2(59), 403-15.

Shapiro M., (1994), "Juridicalization of Politics in the United States," International Political Science Review, 15(2), 101-112.

Shapiro, Martin; Stone Sweet, Alec (2002), On Law, Politics \& Judicialization. Oxford, New York: Oxford University Press.

Smith, Miriam (2005), "Social Movements and Judicial Empowerment: Courts, Public Policy, and Lesbian and Gay Organizing in Canada," Politics \& Society, 33(2), 327-353.

Sousa Santos, Boaventura (1988), "Droit: une carte de lecture déformée. Pour une conception post-moderne du droit," Droit et Société, 10, 363-390.

Sousa Santos, Boaventura (2004), Vers un Nouveau Sens Commun juridique. Droit, science et politique dans la transition paradigmatique, Coll. Droit et Société, série Sociologie, Paris: LGDJ.

Stone Sweet, Alec (1999), "Judicialization and the Construction of Governance," Comparative Political Studies, 32(2), 147-184.

Takamura, Gakuto (2007), "La justice comme vecteur d'un nouvel ordre," in J. Commaille \& M. Kaluszynski (eds.), La fonction politique de la justice. Paris: La Découverte, 213-228.

Tate, C. Neal; Vallinder, Torbjorn (1995), The Global Expansion of Judicial Power. New York: New York University Press. 
Trochev, Alexei (2004), "Less Democracy, More Courts: A Puzzle of Judicial Review in Russia," Law \& Society Review, 38(3), 513-548.

Uprimny Yepes, Rodrigo (2007), "La justice au coeur du politique: potentialités et risques d'une judiciarisation en Colombie", in J. Commaille \& M. Kaluszynski (eds.), La fonction politique de la justice. Paris: La Découverte, 229-250.

Vauchez, Antoine; Willemez, Laurent (2007), La justice face à ses réformateurs (1980-2006). Paris: PUF.

Veltz, Pierre (1998), "La ville, le développement économique et l'emploi: I'agglomération comme échelle pertinente," in Ministère de l'Emploi et de la solidarité, Demain la ville. Vol. 2. Paris: la documentation Francaise, 331-340.

Vigour, Cécile (2006), "Justice: I'introduction d'une rationalité managériale comme euphémisation des enjeux politiques," Droit et Société, 63-64, 425-455.

Weber, Max (1921), Parlament und Regierung im neugeordneten Deutschland. Tübingen: Mohr Siebeck. 